\title{
Use of Virtual Learning on Academic Performance of Js 1 Integrated Science Student in Secondary School in Port Harcourt Local Government Area
}

\author{
Etim, P. J. ${ }^{1}$, Udosen, I. N. ${ }^{2} \&$ Wordu Nkasiobi Chinyeaka ${ }^{3}$ \\ ${ }^{1}$ Department of Educational Technology and Library Science, Faculty of Education, University of Uyo, Uyo, \\ Akwa Ibom State \\ ${ }^{2}$ Department of Educational Technology and Library Science, Faculty of Education, University of Uyo, Uyo, \\ Akwa Ibom State \\ ${ }^{3}$ University of port-Harcourt, Port Harcourt, Nigerian \\ Correspondence: Udosen, I. N., Department of Educational Technology and Library Science, Faculty of \\ Education, University of Uyo, Uyo, Akwa Ibom State. E-mail: id_udo@yahoo.com
}

Received: March 19, 2016

Accepted: April 16, 2016

Online Published: June 22, 2016

doi:10.5539/mas.v10n8p256

URL: http://dx.doi.org/10.5539/mas.v10n8p256

\begin{abstract}
This paper examined the use of virtual learning on the academic performance of JS 1 Integrated Science Students in Secondary Schools in Port Harcourt Local Government Area of Rivers State, Nigeria. In discussing this, it examined the concept of virtual learning instruction, Synchronous and Asynchronous e-learning as compared to face-to-face traditional classroom learning and the advantages and disadvantages of virtual learning. Quasi experimental design was adopted. Population for the study comprised all JS 1 students in public secondary schools in Port Harcourt Local Government Area. Sample size of 200 students were selected from 2,910 JS 1 students in all the public secondary schools in Port Harcourt Local Government Area using the multi-stage sampling technique. Instrument for data collection was an objective Integrated Science performance test (OIPT). Two hypotheses were formulated and tested using Factorial Analysis of Variance (ANCOVA). Result of the analysis showed that there is no significant difference in student's academic performance when virtual learning and expository methods are used in teaching Integrated Science in Junior Secondary class (f1.195 = 1.606, $p>.05$ ) and that there is no significant difference between the academic performance of female and male students when virtual learning and expository methods are used in teaching Integrated Science in JS 1 (F1, $195=$ $717, \mathrm{p}>.05)$. It was therefore recommended that: Teachers should try to apply the virtual learning instruction in the teaching of Integrated Science as this was found to impact on the students achievement positively and that male and female students should be equally engaged in the learning of Integrated Science where VLS is incorp+orated to eliminate the gender bias in sciences.
\end{abstract}

Keywords: virtual learning instruction, integrated science, junior secondary school I, students e-learning, synchronous, asynchronous

\section{Introduction}

Virtual Learning instruction is one of the web-based learning. It is anywhere, anytime instruction delivered over the Internet or a cooperate intranet to browser-equipped learners-Rouse (2005). There are two primary models of Virtual Learning instruction.

Synchronous learning refers to environment in which everyone takes part in learning at the same time. Lecture is an example of synchronous learning in face-to-face environments. Synchronous learning in education is used to help decrease the challenges associated with transactional distance that occur in online education (Joel, 2003). Joel also gave the following as examples of synchronous learning environments namely having students who are watching a live streaming of a class take part in a chat, and having students and instructors participate in a class via a web conference tool such as Black Board Collaborate, Adobe Connect, Web Ex, Skype, etc. Synchronous e-learning lets the teacher conduct classes over the Internet. Moreover, the synchronous technologies also allow people to interact with peers and experts (www.e-learningconsulting.com/consulting/what/synchronous.html). 
Asynchronous learning according to Lad (2012) is a learning that happens independent of time and space. Learners are able to interact with course materials and with each other at a time of their choosing. In addition, Lado opined that asynchronous e-learning gives e-learning much appeal.

Virtual Learning instruction is the perfect solution to meeting the needs of life-long learners because it is available on demand, does not require travelling and has efficient cost. It is a good alternative for independent self-motivated students. Virtual learning uses computer software, the Internet or both to deliver instruction to students. This reduces or eliminates the need for teachers and students sharing a classroom (Van Beek, 2011). It launched in the 1980s when companies started using computer-based programs to train new employees. When Internet was invented, the practice began to grow in efficiency as companies could train new employees in remote locations, as well as chat with them online in order to answer questions. It cut cost and reduced the hiring of trainers.

The main rationale behind the establishment of virtual learning is to prepare students as global citizens who can function and succeed across cultures and environments in an increasingly interdependent world (www.world-globaleducation.edu/01/rationals.htm). Virtual learning environment is a system via the web through which materials for learning is delivered to students. These systems include assessment, student tracking, collaboration and communication tools. They can be accessed both on and off campus. They can support students learning outside the lecture hall at anytime during the day (i.e. Morning, afternoon and night).

There are three theories for virtual learning that support this work. Two theories provide the foundation for online learning. The First one is the cognitive theory which focuses on long and short term memory, reflection and metacognition that calls for knowing and using various strategies. The second theory is the constructivist theory which attempts to engage learners actively as they create knowledge. Lastly is the connection theory which acknowledges the importance of new learning. These three theories are directly implied in this study.

In support of this study, Connolly, Gould and Hainey (2008), in their study found that e-learning is successful and is now supplementing, as well as in some cases replacing expository approaches to teaching and learning and even replacing the traditional Paper Portfolios. It enables institutions to teach not only traditional full-time students but also those who cannot regularly visit the campus due to geographic or time restriction. For example:

- Those on distance learning courses

- Those undertaking evening classes and

- Worker who are also students studying part-time.

\section{Asynchronous Vs. Synchronous E-Learning}

Table 1. Asynchronous Vs. Synchronous E-Learning E-learning (source: Stefan Hrastinski Educause quarterly November, 2008)

\begin{tabular}{llll}
\hline & \multicolumn{1}{c}{ Asynchronous } & \multicolumn{1}{c}{ Synchronous E-Learning } \\
\hline $\begin{array}{l}\text { When to } \\
\text { use }\end{array}$ & $\begin{array}{l}\text { When reflecting on complex issues } \\
\text { When synchronous meetings cannot be } \\
\text { scheduled because of work, family and } \\
\text { other commitment. }\end{array}$ & $\begin{array}{l}\text { Discussing less complex issues. } \\
\text { Getting acquainted. } \\
\text { Planning tasks }\end{array}$ \\
\hline Why? & $\bullet \begin{array}{l}\text { Students have more time to reflect because } \\
\text { the sender does not expect an immediate } \\
\text { answer. }\end{array}$ & $\begin{array}{l}\text { Students become more committed and motivated } \\
\text { because a quick response is expected. }\end{array}$ \\
\hline How? & $\bullet \begin{array}{l}\text { By the use of asynchronous means such as } \\
\text { e-mail, discussion boards, and blogs. }\end{array}$ & $\begin{array}{l}\text { By the use of synchronous means such as } \\
\text { video conferencing, instant message, chat } \\
\text { and complement with face-to-face meetings. }\end{array}$ \\
\hline Examples & $\bullet \begin{array}{l}\text { Students expected to reflect individually on } \\
\text { course topics may be asked to maintain } \\
\text { blog. }\end{array}$ & $\begin{array}{l}\text { Students expected to work in groups may be } \\
\text { advised to use instant message as support for } \\
\text { getting to know each other, exchanging } \\
\text { ideas, and planning tasks. } \\
\text { A teacher who wants to present a concept, } \\
\text { from the interacting in a simplified way } \\
\text { might give an online lecture by video } \\
\text { regarding course topics and critically } \\
\text { assess their peers' ideas may be asked to } \\
\text { participate in online discussions on a } \\
\text { discussion board. }\end{array}$ \\
\hline
\end{tabular}


Virtual learning has the following advantages:

1) Class work can be scheduled around work and family.

2) It reduces travel time and travel cost for off-campus students.

3) Students may have the option to select learning materials that meet their level of knowledge and interest.

4) Students can study anywhere they have access to a computer and Internet connection.

5) Self-paced learning modules allow students to work at their pace.

6) There is a flexibility to join discussions in the bulletin board threaded discussion areas at anytime, or visit classmates and instructors remotely in a chartroom.

7) Instructors/students both report that e-learning fosters more interaction among students and instructors than in large lecture courses.

8) It can accommodate different learning styles and facilitate learning through a variety of activities.

9) It develops knowledge of the Internet and computer skills that will help learners throughout their lives and career. Successfully completing online or computer-based courses builds self knowledge and self confidence and encourages students to take responsibility for their learning.

Virtual learning also has the following disadvantages:

1) Learners with low motivation or bad study habits may lag behind. Without the routine structures of a traditional class, students may yet lose or be confused about course activities and deadlines.

2) Students may feel isolated from the instructor and classmates. Instructor may not always be available when students are studying or need help.

3) Slow internet connections or older computers may make accessing course materials frustrating (i.e. Iowa State University).

Integrated Science is a revolutionary new introductory science curriculum developed at Princeton USA and also used in Nigeria. It is intended for students considering a career in science. The concept of Integrated Science is that it breaks down traditional disciplinary barriers of science subjects into series of courses to be taken by students in junior secondary schools. The intension is to prepare students for any of the core scientific disciplines in the senior secondary (http://www.princeton.edu/ integratedscience/22/3114).

The objective of integrated science is to provide a strong science education with interdisciplinary component which provides opportunities for students' to design their own interdisciplinary course study. It also guides students in developing a wider perspective of scientific concepts with cross disciplinary boundaries (http://www.calendar.ubc.ca $N$ ancouver/index.cfm/teo=12,215,410,428).

Researches carried out by Dienye-Green and Osah-Ogulu (2003) and Edmund (2003) had shown that no research work have been done on the use of virtual learning strategy in teaching integrated science in Port Harcourt Local Government Area of Rivers State. This study is predicated on the fact that students' performance may be facilitated with the use of virtual learning strategy.

The researcher carried out this study using the Junior Secondary School students (JS 1) in the following schools; Community Secondary School Abuloma and Government Secondary School Oroworukwo both in Port Harcourt Local Government Area of Rivers State. Port Harcourt was chosen for this study because the model primary and junior secondary schools the government built that have been in existence and well equipped with computer and Internet facilities. This makes it easy for teachers to use virtual learning strategy in teaching.

Therefore, the study intends to:

1) Find out the academic performance of students, when taught integrated science using virtual learning and expository method of teaching.

2) Find out the academic performance of male and female students when taught using virtual learning and expository methods of teaching.

\section{Hypotheses}

Two hypotheses were postulated to direct the study:

1) There is no significant difference in students' academic performance when Virtual Learning and expository methods are used in teaching Integrated Science in JSS I students. 
2) There is no significant difference between the academic performance of female and male students when Virtual Learning and expository methods are used in teaching integrated science in JS1 students.

\section{Methodology}

The adopted research design for this study is the quasi experimental design involving pre-test-post-test and non randomized control group. In a pre-test-post-test statistical design, a single group of participants is measured on the dependent variable both before and after the manipulation of the independent variable and is increased by adding a control group. One group serves as the treatment group and the other as the experimental group.

The population for this study is 2,910 integrated science students in JS I in Port Harcourt Local Government Area (SSMB, 2015).

The purposive sampling technique is adopted for this work. By this technique 100 JS1 students were selected from Community Secondary School, Abuloma while 100 students were selected from Government Secondary School, Oroworukwo. This brings the total population of selected students for this study to 200 students. The schools were selected based on the availability of Internet services.

\section{Development of Research Instrument}

Two instruments were developed for this study. One is the conventional lesson plan taught using the discussion methods and the other is a lesson package taught via the Internet. The topic taught was chosen from the Rivers State Junior Secondary School module for JSS 1. Achievement test called Integrated Science Performance Test (ISPT) instrument was developed for both groups to respond to. The instrument was 10 items' subjective integrated science performance test, the test was used to determine the performance of JS 1 students when taught wit virtual learning strategy and the expository methods to compare the academic performance of the two groups.

\section{Validity of Instrument}

The instruments were validated using construct validations by experts in test and measurement. They looked at the appropriateness of items by correcting grammatical errors and structure of the items.

\section{Reliability of the Instrument}

The result obtained in the administration to 20 students who did not take part in the main studies was subjected to Kuber-Richardson formula-12 reliability test statistics. The result showed high reliability coefficients of 85 . Therefore, the instrument was considered to be highly reliable and useful in collecting the required data for the study.

\section{Administration of Research Instrument}

From each school classes A and B were used as experimental and control groups respectively. Each class had 50 students. The experimental groups were treated with the instructional package.

The test instrument was administered to both groups as pre-test before instruction took place and the scores recorded. After treatment, the same test instrument was also administered to both groups and the scores were also recorded.

The Instructional package was developed based on the ASSURE Model. This model guided the development of the instructional packages on Virtual Learning strategy on the topic HEREDITY to be taught online and in the traditional classroom to JS1 students being the subject of the study.

The ASSURE model was considered appropriate for these two strategies for modification and use by teachers in the regular classroom to ensure the effectiveness of instruction.

The target audience characteristics were analyzed. Expected outcomes or specific objectives of the lesson stating the strategies for lesson delivery was also stated including the materials to be used for the lesson.

Instruction was given. The students' responses were noted and then the students were evaluated. The use of the ASSURE model in the development of this Instructional package will enhance the effectiveness of learning and stimulate learning. Increased student's interest in learning increases students' knowledge and accessibility of the Internet. Enhanced self-independence in learning increases students' academic performance. 


\section{Results}

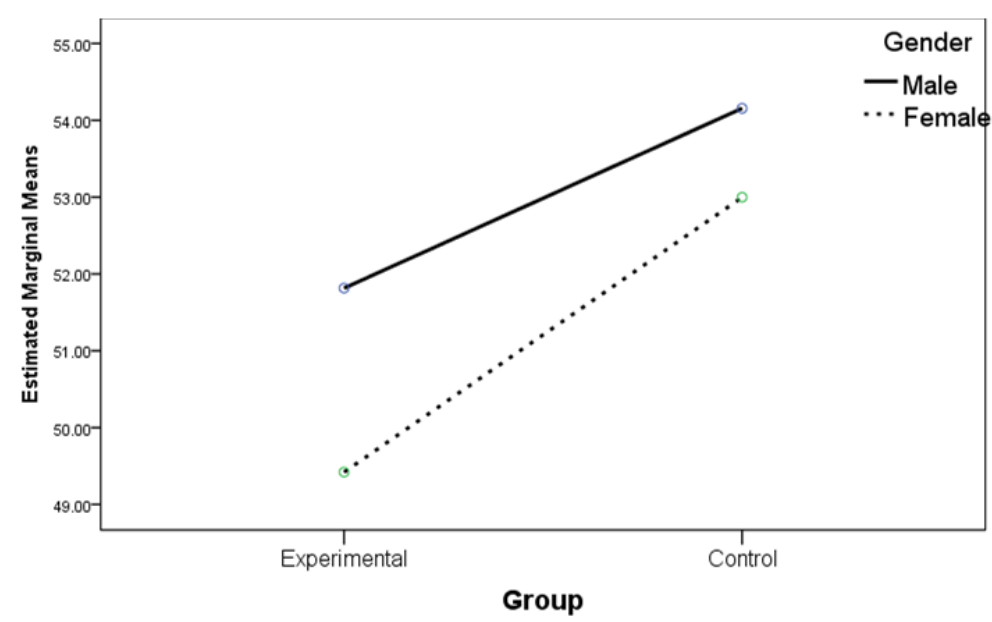

Covariates appearing in the model are evaluated at the following values: pretest $=46.9500$

Figure 1. Estimated marginal means of posttest on student achievement

Table 2. Summary of Factorial Analysis of variance (ANCOVA) on difference in student academic performance based on treatment and gender respectively

\begin{tabular}{lrrrrr}
\hline Source of variation & Type III Sum of Squares & \multicolumn{1}{c}{ Df } & Mean Square & \multicolumn{1}{c}{ F } & \multicolumn{1}{c}{ Sig. } \\
\hline Corrected Model & $593.639^{\mathrm{a}}$ & 4 & 148.410 & .700 & .593 \\
Intercept & 61397.616 & 1 & 61397.616 & 289.570 & .000 \\
Pretest & 1.954 & 1 & 1.954 & .009 & .924 \\
Group & 340.563 & 1 & 340.563 & 1.606 & .207 \\
Gender & 152.117 & 1 & 152.117 & .717 & .398 \\
Group * Gender & 18.458 & 1 & 18.458 & .087 & .768 \\
Error & 41345.861 & 195 & 212.030 & & \\
Total & 581700.000 & 200 & & & \\
Corrected Total & 41939.500 & 199 & & & \\
\hline
\end{tabular}

a. $\mathrm{R}$ Squared $=.014$ (Adjusted R Squared $=-.006$ )

Table 1 shows that there is no significant difference in students' academic performance when Virtual Learning and expository methods are used in teaching Integrated Science in Junior secondary class 1 (F1, 195=1.606, $\mathrm{p}>.05$ ). The hypothesis one is retained. The result on Table 1 also indicated that there is no significant difference between the academic performance of female and male students when Virtual Learning and expository methods are used in teaching integrated science in $\operatorname{JSC} 1(\mathrm{~F} 1,195=.717, \mathrm{p}>.05)$. The null hypothesis two is retained.

\section{Discussion of Findings}

The result on figure 1 indicated that the performance of students in the control group was not slightly higher than that of their counterparts in the experimental group. When put to statistical test, the result indicated that there is no significant difference in students' academic performance when Virtual Learning and expository methods are used in teaching Integrated Science in junior secondary class 1 . The null hypothesis one was retained at .05 level of significance. The present study was inconsistent with an earlier study by Connolly, Gould and Hainey (2008), This found that e-learning is successful and is now supplementing, as well as in some cases replacing expository approaches to teaching and learning and even replacing the traditional Paper Portfolios.

Moreover, the result in Figure 1 indicated that male students slightly outperformed their female counterparts in terms of academic performance in integrated science in the experimental group. When put to statistical test, the result was that there is no significant difference between the academic performance of female and male students when Virtual Learning and expository methods are used in teaching integrated science in JSC1. The null hypothesis two is accepted. Patrick and Powell (2009) found that there is no significant difference in student 
performances in online courses versus traditional face-to-face courses in their study on the summary of research on the effectiveness of K-12 online learning.

\section{Conclusion}

The virtual learning strategy (VLS) impacted significantly on the academic performance of students. The VLS was not gender biased in terms of improvement of students' learning, since there was not significant gender difference in the achievement of the students in integrated science.

\section{Recommendations}

Based on the findings of the present study the following recommendations were made:

1) Teachers should try to apply the virtual learning strategy in the teaching of integrated science as this was found to impact on the students' achievement positively.

2) Male and female students should be equally engaged in the learning of integrated science where VLS is incorporated to eliminate the gender bias in sciences

\section{References}

Advantages and Disadvantages of Virtual Learning. http://www.oso.iastate.edu/osc/academic/ elearner/advantage.html Retrieved on 16/03/2014

Dienye, G. R., \& Osah-Ogulu, D. J. (2003). Integrated Science Teachers' Instructional Competencies (pp. 149-158) publishing modes and articles. http://www.tandfonline.com Retrieved on 18/05/2014

Hrastinski, S. (2008). Asynchronous and Synchronous e-learning Methods. Educause Quarterly.

Joel (2003). http://www.en.wikipedia.org/wiki/synchronous_learning retrieved on 16/03/2014

Lodo, A. (2012). Asynchronous Learning. Faculty of Computer Science for Business Management, Romanian-American University Bucharest, Romania.

Patrick, S. \& Powell, A. (2009). A Summary of Research on the Effectiveness of K-12 Online Learning INACOL. International Association for K-12 Online Learning. Gallows Rd. Dianna.

Rouse, M. (2003). Distance Learning (e-learning).

Sletan Hrastinski Educause quarterly Nov 2008.

Van Beek, M. (2011). Virtual Learning Centre for Public Policy. West Main Street Midland Michigan.

\section{Appendices}

Instructional package on integrated science for use of the expository method

Subject: Integrated Science

Topic: Heredity

Class: $\quad$ JS 1

No. in Class: $\quad 100$

Age: $\quad 10$ years

Gender: $\quad$ Mixed

Lesson duration: 2 periods of 45 minutes each.

The lesson will cover the following:

1. Definition of heredity.

2. Cellular Basis of Heredity

3. What are chromosome

4. Transmitted traits

5. Dominant and Recessive genes

Specific Objectives: By the end of the lesson, students should be able to:

$>$ Define the term heredity in writing within 6 seconds with no reference to a book.

> In 60 seconds list 4 basic points by naming that explains the cellular basis of heredity. 
$>$ Identify by drawing in the class, pairs of chromosome and also state how many pairs are found in man in 8 minutes.

$>$ Identify by drawing a dominant and a recessive gene in the class in 5 minutes.

Instructional materials: Charts and posters of the diagrams of heredity.

Entry Behaviors: Students are asked to mention who they look like in their families and in what ways they look like these persons.

\section{Lesson Development}

Step 1: Teacher explains that heredity is the Transmission of characteristics from parents to their progeny or offsprings. Thus tall parents often have tall children. Similarly, it is possible for one to bear some special or prominent characteristics that resembles that of your parents, such as size of eyes, and skin color.

Step 2: Teacher displays the poster of a cell and explains that all living things are made up of cells.

The cell membrane-outer covering of the cell.

Cytoplasm-is the inside of the cell.

The Nucleus-is found in the middle of the cell and is known as the heart of the cell and within the cell are structures called chromosomes. They are molecules which govern the characteristics transmitted from parents to offspring and are called sex cells they also determine the sex of a child.

Students Activities: The students respond to teaching by identifying parts of the cell and naming them.

Step III: Teacher explains that Genes are Di-oxy-nutric Acids (DNA) which are responsible for all transmitted traits or characteristics from parents to offsprings.

The traits that are shown are termed Dominant while the hidden traits are termed Recessive.

Students' activities: Students draw the diagram of crossing breeding of pea to show a Hybrid and they identify the dominant color as shown in the diagram.

\section{Conclusion}

The lesson is summarized by mentioning and writing the salient points on the board and drilling the students on them.

Evaluation: An end of lesson test is given by the teacher to assess the student using Integrated Science Performance Test (ISP).

\section{Instruction for Data Collection - Integrated Science Performance Test}

1. What is heredity

2. All living things are made of up of

3. The outer covering of a cell is known as

4. The nucleus is also called and is found in the of the cell.

5. .................... is responsible for all transmitted traits in living things.

6. The invisible traits are called

7. The transmitted traits that are visible are called

8. How do chromosomes appear in man

9. How many chromosomes are found in man

10. What is a Hybrid

\section{Univariate Analysis of Variance}

\section{Between-Subjects Factors}

\begin{tabular}{llr}
\hline & Value Label & $\mathrm{N}$ \\
\hline 1 & Experimental & 100 \\
2 & Control & 100 \\
1 & Male & 82 \\
2 & Female & 118 \\
\hline
\end{tabular}




\section{Descriptive Statistics}

\begin{tabular}{llcrr}
\hline Dependent Variable: & posttest & & & \\
\hline Group & Gender & Mean & Std. Deviation & $\mathrm{N}$ \\
\hline Experimental & Male & 51.8605 & 17.89597 & 43 \\
& Female & 49.4737 & 16.84181 & 57 \\
& Total & 50.5000 & 17.25478 & 100 \\
\hline Control & Male & 54.1026 & 11.17279 & 39 \\
& Female & 52.9508 & 11.00670 & 61 \\
& Total & 53.4000 & 11.02980 & 100 \\
\hline Total & Male & 52.9268 & 15.02983 & 82 \\
& Female & 51.2712 & 14.17513 & 118 \\
& Total & 51.9500 & 14.51727 & 200 \\
\hline
\end{tabular}

\section{Tests of Between-Subjects Effects}

\begin{tabular}{lrrrrr}
\hline Dependent Variable: posttest & \multicolumn{7}{l}{} \\
\hline Source & Type III Sum of Squares & \multicolumn{1}{c}{ Df } & Mean Square & \multicolumn{1}{c}{ F } & \multicolumn{1}{c}{ Sig. } \\
\hline Corrected Model & $593.639^{\mathrm{a}}$ & 4 & 148.410 & .700 & .593 \\
Intercept & 61397.616 & 1 & 61397.616 & 289.570 & .000 \\
pretest & 1.954 & 1 & 1.954 & .009 & .924 \\
Group & 340.563 & 1 & 340.563 & 1.606 & .207 \\
Gender & 152.117 & 1 & 152.117 & .717 & .398 \\
Group * Gender & 18.458 & 1 & 18.458 & .087 & .768 \\
Error & 41345.861 & 195 & 212.030 & & \\
Total & 581700.000 & 200 & & & \\
Corrected Total & 41939.500 & 199 & & & \\
\hline
\end{tabular}

a. R Squared $=.014$ (Adjusted R Squared $=-.006)$

\section{Profile Plots}

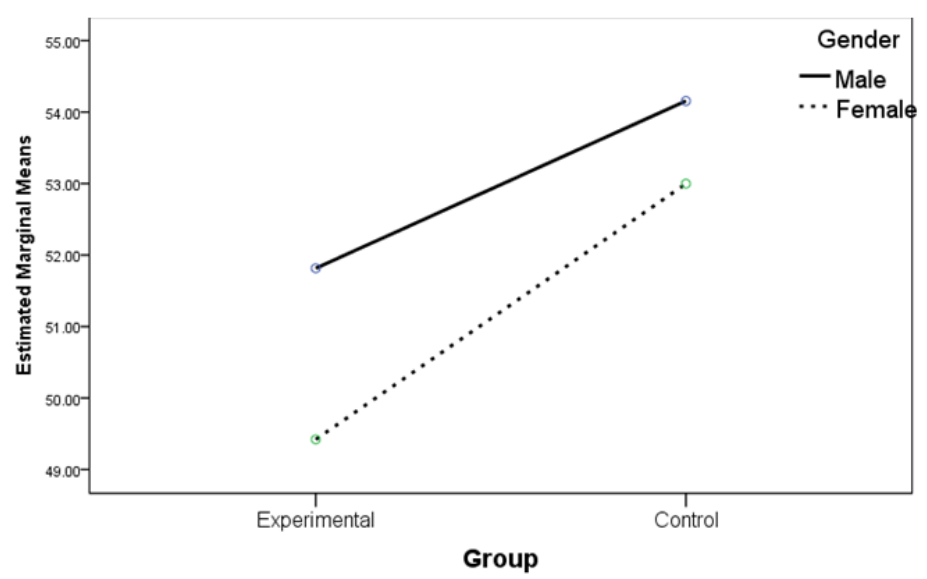

Covariates appearing in the model are evaluated at the following values: pretest $=46.9500$

Figure 1. Estimated marginal means of posttest on student achievement

\section{Copyrights}

Copyright for this article is retained by the author(s), with first publication rights granted to the journal.

This is an open-access article distributed under the terms and conditions of the Creative Commons Attribution license (http://creativecommons.org/licenses/by/3.0/). 